Check for updates

Cite this: Chem. Sci., 2017, 8, 5953

\title{
Enhancing the reactivity of nickel(II) in hydrogen evolution reactions (HERs) by $\beta$-hydrogenation of porphyrinoid ligands $\uparrow$
}

\author{
Zhuo-Yan Wu, (D) Teng Wang, Yin-Shan Meng, (D) Yu Rao, (D) Bing-Wu Wang, (D) * \\ Jie Zheng, (D) * Song Gao (D) and Jun-Long Zhang (D)*
}

Fine-tuning of the porphyrin $\beta$-periphery is important for naturally occurring metal tetrapyrroles to exert diverse biological roles. Here we describe how this approach is also applied to design molecular catalysts, as exemplified by $\mathrm{Ni}(॥)$ porphyrinoids catalyzing the hydrogen evolution reaction (HER). We found that $\beta$-hydrogenation of porphyrin remarkably enhances the electrocatalytic HER reactivity (turnover frequencies of 6287 vs. $265 \mathrm{~s}^{-1}$ for $\mathrm{Ni}(॥)$ chlorin (Ni-2) and porphyrin (Ni-1), and of 1737 vs. 342 $\mathrm{s}^{-1}$ for $\mathrm{Ni}(\mathrm{I})$ hydroporpholactone $(\mathrm{Ni}-4)$ and porpholactone ( $\left.\mathrm{Ni}-3\right)$, respectively) using trifluoroacetic acid (TFA) as the proton source. DFT calculations suggested that after two-electron reduction, $\beta$ hydrogenation renders more electron density located on the $\mathrm{Ni}$ center and thus prefers to generate a highly reactive nickel hydride intermediate. To demonstrate this, decamethylcobaltocene $\mathrm{Co}(\mathrm{Cp} *)_{2}$ was used as a chemical reductant. $[\mathrm{Ni}-2]^{2-}$ reacts $\mathrm{ca}$. 30 times faster than $[\mathrm{Ni}-1]^{2-}$ with TFA, which is in line with the electrocatalysis and computational results. Thus, such subtle structural changes inducing the distinctive reactivity of $\mathrm{Ni}\left({ }_{1}\right)$ not only test the fundamental understanding of natural Ni tetrapyrroles but also provide a valuable clue to design metal porphyrinoid catalysts.

Received 9th May 2017

Accepted 18th June 2017

DOI: $10.1039 / \mathrm{c} 7 \mathrm{sc} 02073 \mathrm{~b}$

rsc.li/chemical-science pyrrole, other than protoporphyrin (Fig. 1). The interrupted conjugation arising from the reduced pyrrole(s) renders distortions of the porphyrin ring, a larger binding cavity and a more electron rich $\mathrm{Ni}$ center after one or two electron reduction, as revealed by electrochemical studies on $\beta$-hydroporphyrin models. ${ }^{\mathbf{a} a-\boldsymbol{d}}$ Encouraged by these pioneering studies, we herein report the first example showing that $\beta$-hydrogenation of porphyrinoids significantly enhances the reactivity of nickel(II) in the hydrogen evolution reaction (HER), which demonstrates the importance of bioinspired $\beta$-modification in designing molecular catalysts.

and related optoelectronic materials. ${ }^{4 a-c}$ In contrast to the tremendous progress in the physicochemical properties, applying the structural insights gained from natural tetrapyrroles to catalysis had been long ignored. In fact, $\beta$-modification is of equal importance for metalloenzymes, as exemplified by $\mathrm{Ni}(\mathrm{II})$ tetrapyrrole cofactors found in reductases. ${ }^{5 \boldsymbol{a}, \boldsymbol{b}}$ These $\mathrm{Ni}$ cofactors such as $\mathrm{F}_{430}$ coenzymes $^{6 a, b}$ and tunichlorin ${ }^{7 a, b}$ possess either corphin or chlorin, and feature at least one reduced

Beijing National Laboratory for Molecular Sciences, State Key Laboratory of Rare Earth Materials Chemistry and Applications, College of Chemistry and Molecular Engineering, Peking University, Beijing 100871, P. R. China. E-mail: zhangjunlong@ pku.edu.cn; wangbw@pku.edu.cn; zhengjie@pku.edu.cn

$\dagger$ Electronic supplementary information (ESI) available. CCDC 1528290, 1554494 and 1554445. For ESI and crystallographic data in CIF or other electronic format see DOI: $10.1039 / \mathrm{c} 7 \mathrm{sc0} 02073 \mathrm{~b}$

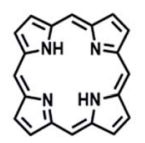

Porphyrin

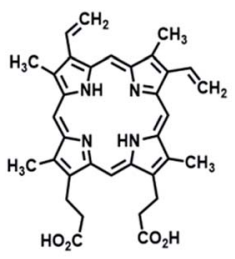

Protoporphyrin IX

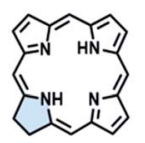

Chlorin

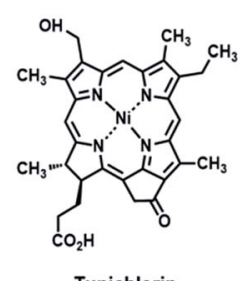

Tunichlorin

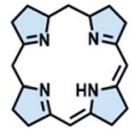

Corphin

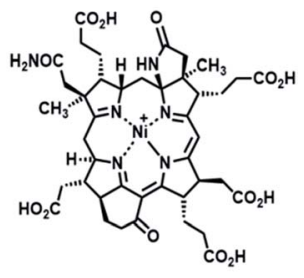

Factor F 430
Fig. 1 Selected examples of natural tetrapyrroles and synthetic models. 
The hydrogen evolution reaction (HER) is a fundamental process in water splitting to produce hydrogen energy as a potential alternative to traditional fossil fuels. ${ }^{9 a-d}$ On the route to seek earth-abundant metals to replace noble metals, ${ }^{10 a-f}$ nickel(II) complexes of porphyrins have attracted increasing attention due to the combination of the pivotal role of $\mathrm{Ni}$ (II) in [NiFe] hydrogenases ${ }^{11 a, b}$ and the sophisticated porphyrin chemistry. ${ }^{12 a-e}$ Recently Cao and co-workers proposed a oneelectron reduction and bimetallic homolysis mechanism based on a $\mathrm{Ni}(\mathrm{II})$ porphyrin with meso-pentafluorophenyl substituents. ${ }^{13}$ Nocera and co-workers constructed a " 2 nd $c o o r-$ dination sphere" around the $\mathrm{Ni}$ (II) center using a hangman type porphyrin, which demonstrated a hydrogen bond facilitating proton coupled electron transfer process. ${ }^{14}$ More importantly, the same group found a Ni(II) phlorin intermediate during HER, in which a proton was added to the meso-carbon appended to the hangman moiety. ${ }^{15}$ The appearance of the phlorin intermediate indicated that it was necessary to investigate the hydroporphyrin with interrupted conjugation.

As part of our continued effort to unravel the effect of $\beta$ modification on the functions of porphyrins, ${ }^{\mathbf{1 6 a}-\boldsymbol{d}}$ in the present study we report the synthesis, electrochemical characterization and HER reactivity of nickel complexes of porphyrin (Ni-1), chlorin (Ni-2), porpholactone (Ni-3) and $\beta$-hydroporpholactone (Ni-4). Importantly, as a result of $\beta$-hydrogenation, Ni-2 and Ni-4 exhibited significantly enhanced electrocatalytic HER reactivity (determined by turnover frequencies, TOFs) which was 24 and 5 times that of the corresponding porphyrin (Ni-1) and porpholactone (Ni-3), respectively. More importantly, DFT calculations suggest that $\beta$-hydrogenation renders more electron rich $\mathrm{Ni}$ centers in the two-electron reduced $[\mathrm{Ni}-2]^{2-}$ and $[\mathrm{Ni}-4]^{2-}$ than the analogues $[\mathrm{Ni}-1]^{2-}$ and $[\mathrm{Ni}-3]^{2-}$, and thus tends to form active nickel hydride intermediates. This is supported by the titration of trifluoroacetic acid (TFA) to two-electron reduced nickel complexes, in which $[\mathrm{Ni}-2]^{2-}$ reacts $c a .30$ times faster than $[\mathrm{Ni}-1]^{2-}$. Therefore, this work demonstrates that such a subtle structural modification inspired by nature is instrumental to the observation and investigation of catalytic properties of metal porphyrinoid complexes.

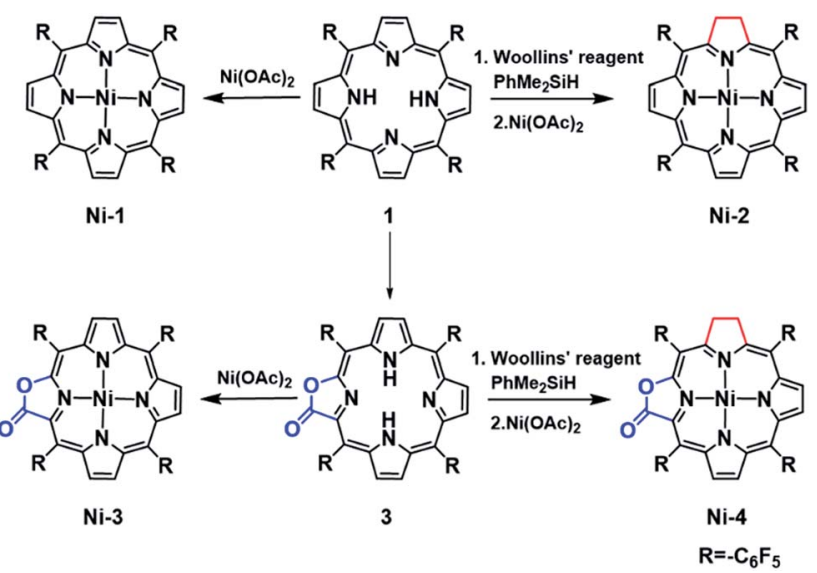

Scheme 1 The synthetic procedures for $\mathrm{Ni}-1, \mathrm{Ni}-2, \mathrm{Ni}-3$ and $\mathrm{Ni}-4$.

\section{Results and discussion}

\section{Synthesis and characterization}

In this work, free-base porphyrinoids 1-4 were synthesized in good yields according to the literature. ${ }^{\mathbf{1 6 c , 1 7}}$ Nickel complexes (Scheme 1) were prepared by refluxing excess nickel(II) acetate (30 equiv.) with the corresponding porphyrinoid ligands in dimethylformamide (DMF) under a $\mathrm{N}_{2}$ atmosphere. Four nickel complexes were fully characterized by UV-vis absorption, and ${ }^{1} \mathrm{H},{ }^{19} \mathrm{~F},{ }^{13} \mathrm{C}-\mathrm{NMR}$ and HR ESI-MS spectroscopes and spectrometers (ESI $\dagger$ ). Ni-2 and $\mathrm{Ni}-4$ were diamagnetic for the low spin $\mathrm{d}^{8}$ electronic structure and showed proton signals at 3.93 and 3.77-3.65 ppm, respectively, which can be assigned to the hydropyrrole moiety. Compared to Ni-1 and Ni-3, the $\beta$-hydroanalogues Ni-2 and Ni-4 exhibited two bathochromic Q-bands centered at 576 or 565 and 617 or $613 \mathrm{~nm}$ in acetonitrile, which is also the characteristic absorption pattern of metal chlorins arising from lower molecular symmetry.

Crystals of Ni-2, Ni-3 and Ni-4 were obtained by slow evaporation of a dichloroethane/ $n$-hexane solution. As shown in Fig. 2, the crystal structure of Ni-2 (CCDC: $1528290 \dagger$ ) displays the typical ruffling distortion with the $\mathrm{Ni}$ atom centered at the N4 planar squares. Although it is difficult to distinguish the hydropyrrole ring from the other ones due to the symmetry condition of the $I \overline{4} 2 d$ space group, the average pyrrole $\mathrm{C}-\mathrm{C}$ bond length $(\mathrm{C} 2-\mathrm{C} 3,1.383 \AA)$ of Ni-2 is $0.037 \AA$ longer than that of Ni1 (C11-C13, $1.346 \AA$ ). ${ }^{13}$ Similarly, the hydropyrrole ring on Ni-3 (CCDC: $1554494 \dagger$ ) can be distinguished through comparison of the $\mathrm{C}-\mathrm{C}$ bond length with Ni-4 (CCDC: 1554445†) (C1-C(O)2, $1.338 \AA$ and $\mathrm{C} 3-\mathrm{C} 4,1.341 \AA$ for Ni-3 and C1-C(O)2, $1.404 \AA$ for $\mathrm{Ni}-4)$. In addition, $\mathrm{Ni}-4$ displays the typical ruffling distortion with the Ni-N bond measuring $1.921 \AA$ A, however Ni-3 displays a planar construction with a Ni-N bond of $1.950 \AA$. The shorter $\mathrm{Ni}-\mathrm{N}$ bond induces steric strain on $\mathrm{Ni}-4$, the release of which is the driving force for easier reduction of the nickel complexes. ${ }^{1 b}$

\section{Electrochemistry}

Cyclic voltammograms of $\mathrm{Ni}$ complexes in acetonitrile using $0.10 \mathrm{M}{ }^{n} \mathrm{Bu}_{4} \mathrm{NPF}_{6}$ as the supporting electrolyte are shown in Fig. S18. $\dagger$ Both Ni-1 and Ni-2 display two distinct reversible oneelectron diffusion controlled reductions $(-1.27$ and $-1.83 \mathrm{~V}$ for $\mathrm{Ni}-1$, and -1.28 and $-1.77 \mathrm{~V}$ for $\mathrm{Ni}-2)$, referenced to the standard reduction potential of $\mathrm{Fc}^{+} / \mathrm{Fc}$. According to previous reports, ${ }^{\mathbf{1 8 a}, \mathbf{1 8 b}}$ the insertion of an electron deficient oxazolone moiety lowers the energy levels of the ligand LUMOs and thus we could observe the positive shift of the reduction potentials of $\mathrm{Ni}-3$ to Ni-1. However, Ni-4 displayed more negative reduction potentials than Ni-3 $(-0.99$ and $-1.59 \mathrm{~V}$ for $\mathrm{Ni}-3$, and -1.14 and $-1.74 \mathrm{~V}$ for $\mathrm{Ni}-4)$, indicating that $\beta$-hydrogenation increases the energy levels of LUMOs in porpholactones.

Spectroelectrochemistry of the Ni(II) complexes was performed to monitor the spectral changes during the reduction process. As shown in Fig. 3, one-electron reduction ( $c a .-1.3 \mathrm{~V}$ ) of Ni-1 and Ni-2 caused a slight decrease and hypsochromic shift of the Soret and Q bands, suggesting the formation of a formal $\mathrm{Ni}^{\mathrm{II} / \mathrm{I}}$ couple according to previous studies by Savéant ${ }^{\mathbf{1 9}}$, 


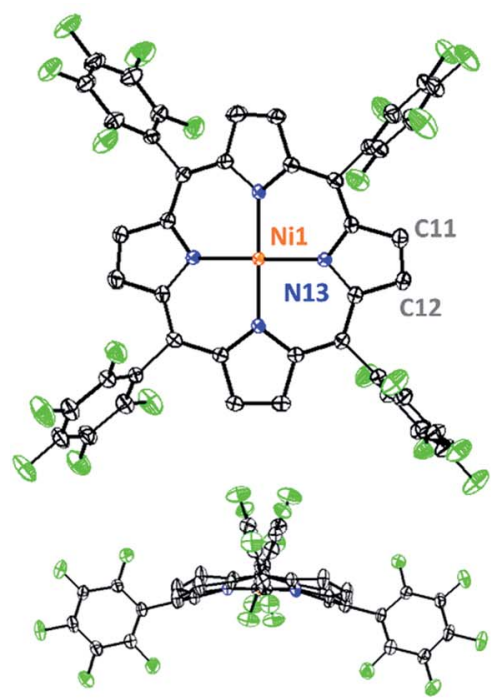

$\mathrm{Ni}-2$
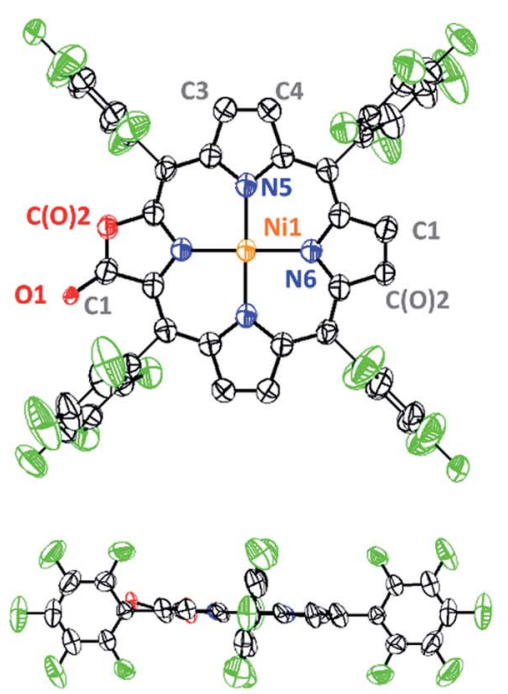

$\mathrm{Ni}-3$
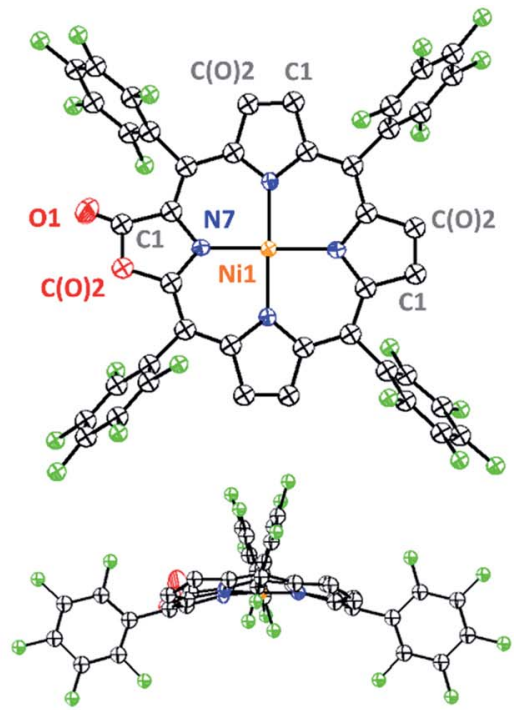

$\mathrm{Ni}-4$

Fig. 2 ORTEP drawings of Ni-2, Ni-3 and Ni-4. The hydrogen atoms and solvent molecules are omitted for clarity. Thermal ellipsoids are drawn with $50 \%$ probability. The lactone ring in $\mathrm{Ni}-3$ shows disorder at the oxazolone and the opposite position while the $\mathrm{Ni}-4$ and $\mathrm{Ni}-2$ show disorder at all four $\beta$-peripheries.
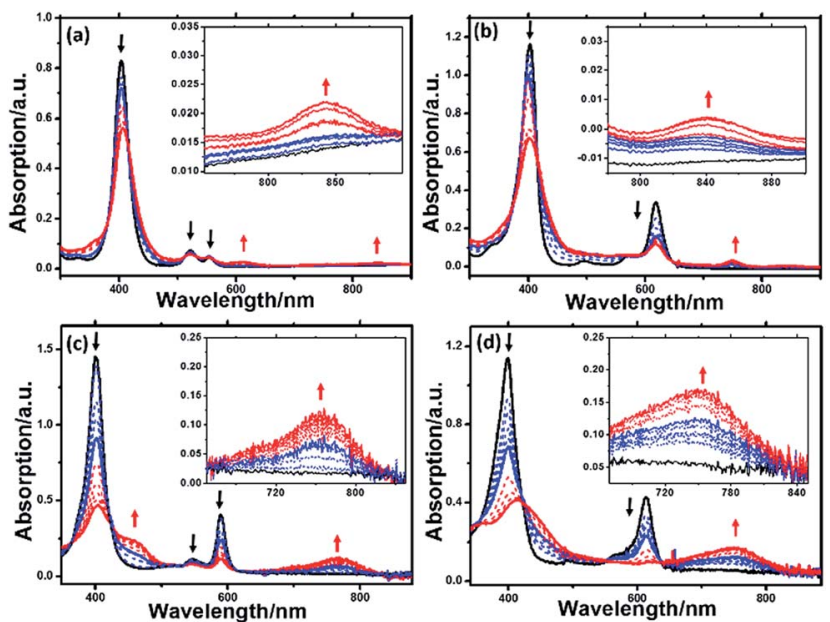

Fig. 3 UV-vis absorption spectra of (a): $\mathrm{Ni}-1$ (black), [Ni-1 $]^{-}$(blue), and $[\mathrm{Ni}-1]^{2-}$ (red), (b): Ni-2 (black), [Ni-2] $]^{-}$(blue), and [Ni-2 ${ }^{2-}$ (red) (c): $\mathrm{Ni}-3$ (black), [Ni-3] ${ }^{-}$(blue), and $[\mathrm{Ni}-3]^{2-}$ (red) and (d): Ni-4 (black), $[\mathrm{Ni}-4]^{-}$ (blue), and $[\mathrm{Ni}-4]^{2-}$ (red) in acetonitrile using thin-layer spectroelectrochemistry. Insets: enlarged views of the absorbance at $750-850 \mathrm{~nm}$ for $\mathrm{Ni}-1$ and $\mathrm{Ni}-2$, and $700-840 \mathrm{~nm}$ for $\mathrm{Ni}-3$ and $\mathrm{Ni}-4$.

Brückner $^{20}$ and others. ${ }^{21 a, b}$ When $c a .-1.85 \mathrm{~V}$ was applied, the Soret and $\mathrm{Q}$ bands of $[\mathrm{Ni}-1]^{2-}$ decreased in intensity, accompanied by the appearance of two broad bands at 621 and $850 \mathrm{~nm}$, thus indicating the formation of a typical porphyrinic dianion. ${ }^{8 a, 22}$ For $[\mathrm{Ni}-2]^{2-}$, the broad band centered at $752 \mathrm{~nm}$ is assigned to the porphyrin $\pi$-anion radical. ${ }^{8 a, 23 a, b}$ This assignment is also supported in the context of DFT calculation results. For the porpholactone analogues $\mathrm{Ni}-\mathbf{3}$ and $\mathrm{Ni}-\mathbf{4}$, it is difficult to distinguish the electronic structures from the UV-vis spectra. When they were reduced at $c a$. -1.2 or $-1.85 \mathrm{~V}$, the intensity of the Soret and $\mathrm{Q}$ bands decreased with red-shift and an absorption peak centered at $750 \mathrm{~nm}$ appeared, indicating that the electrons were delocalized on the macrocycle. Definitive assignment of the electronic structures of $\mathrm{Ni}$ complexes will be further discussed in the context of DFT calculations.

\section{Electrocatalysis hydrogen production}

The HER activities of the four nickel(II) complexes were evaluated by successive cyclic voltammograms in acetonitrile using TFA $\left(\mathrm{p} K_{\mathrm{a}}=12.7\right.$ in $\left.\mathrm{CH}_{3} \mathrm{CN}\right)$ as a proton source. Electrocatalytic production of $\mathrm{H}_{2}$ was confirmed by gas chromatographic analysis, and the faradaic yields of the four complexes were almost above $90 \%$ based on the amount of $\mathrm{H}_{2}$ produced (Fig. S21 $\dagger$ ). There was no observable decomposition of the Ni complexes during HER, according to LDS (Fig. S22 $\dagger$ ), TEM (Fig. S23†) and UV-vis absorption spectra (Fig. S26 $\dagger$ ) of the reaction solution before and after electrolysis. In addition, SEM and EDX (Fig. S25 $\dagger$ ) of the glassy carbon working electrode before and after the HER reaction showed no nickel film deposition on the electrode and thus exclude the possibility of free Ni(II) ions from the Ni complexes being active species. The HER experiments using the dissolved $\mathrm{Ni}(\mathrm{II})$ salts of $\mathrm{Ni}(\mathrm{OTf})_{2}$ (Fig. S24 $\dagger$ ) showed a relatively high overpotential and low catalytic activity, thus we excluded the possibility of the dissolved Ni(II) salts being active intermediates.

In the presence of TFA, an S-shaped irreversible catalytic response for proton reduction triggered at $c a$. $-1.80 \mathrm{~V}$ was observed for the four nickel complexes, as shown in Fig. 4. As shown in Fig. $4 \mathrm{c}$ and $\mathrm{S} 19, \dagger \mathrm{Ni}-1$ reached its maximum turnover frequency when it was applied with $180 \mathrm{mM}$ TFA (Fig. S19†). Here, we roughly estimated the maximum TOF of $265 \mathrm{~s}^{-1}$ using eqn (1) in the ESI $\dagger$ for $\mathrm{Ni}-1$ from the ratio of the maximum catalytic current $i_{\text {cat }}$ to the peak current $i_{\mathrm{p}}\left(i_{\text {cat }} / i_{\mathrm{p}}\right)$ with TFA (180 

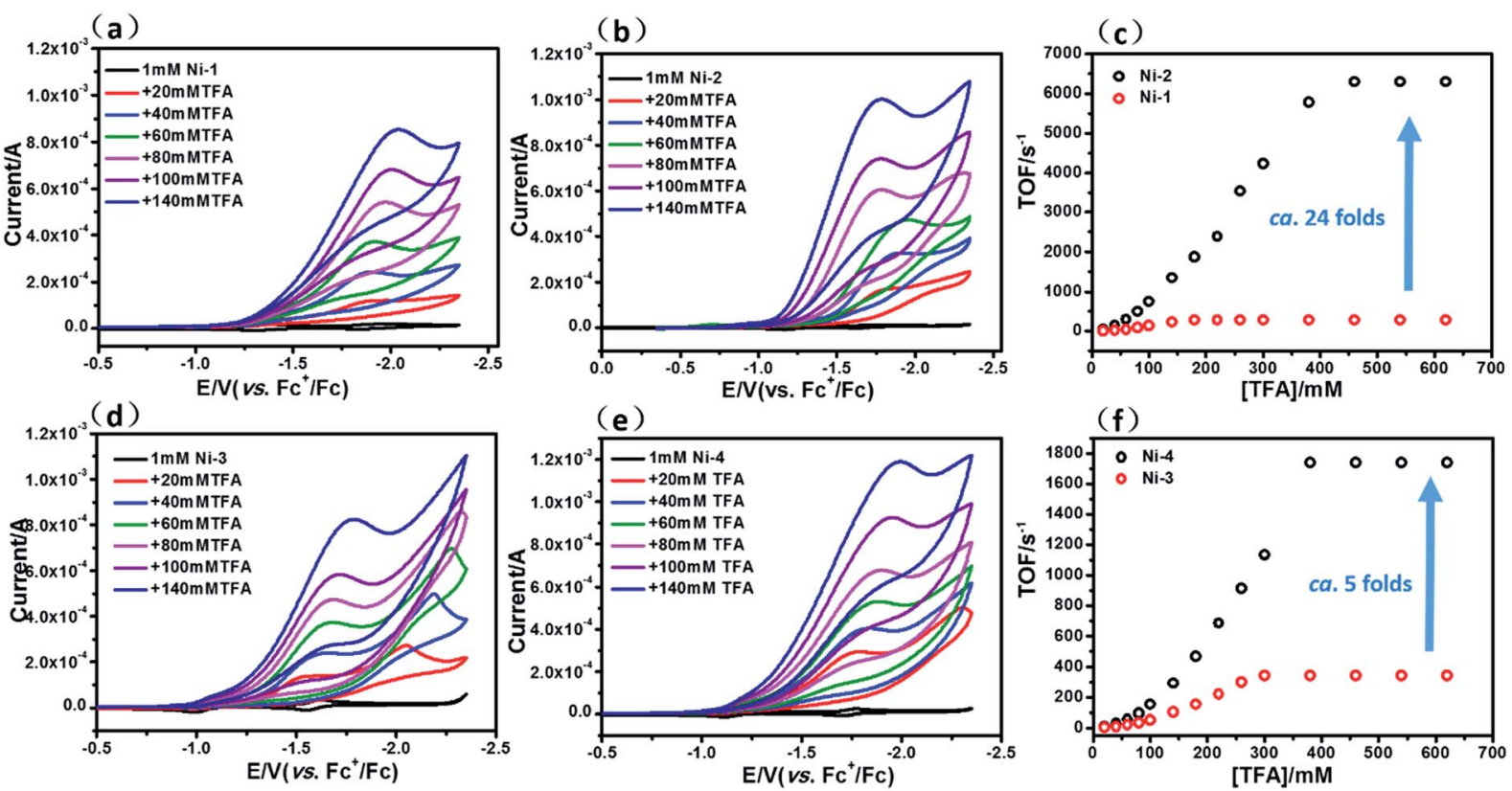

Fig. 4 Successive cyclic voltammograms of $1.0 \mathrm{mM} \mathrm{Ni-1}$ (a), Ni-2 (b), Ni-3 (d) and Ni-4 (e) in $\left.\mathrm{CH}_{3} \mathrm{CN}_{(0.10 ~} \mathrm{M}^{n} \mathrm{Bu}_{4} \mathrm{NPF}_{6}\right)$ at increasing concentrations of TFA from $20 \mathrm{mM}$ to $140 \mathrm{mM}$. Conditions: $3 \mathrm{~mm}$ glassy-carbon working electrode; $25^{\circ} \mathrm{C} ; \mathrm{scan}$ rate: $100 \mathrm{mV} \mathrm{s}{ }^{-1}$. Graphs (c) and (f) show the TOFs vs. concentrations of TFA.

$\mathrm{mM}$ ). Surprisingly, Ni-2 displayed significantly enhanced catalytic reactivity up to a maximum TOF of $6287 \mathrm{~s}^{-1}$ (ca. 24 times greater than that of $\mathrm{Ni}-\mathbf{1})$ when the concentration of TFA reached $460 \mathrm{mM}$. Similar enhancement of the HER reactivity (Fig. S19 $\dagger$ ) but to a lesser extent was observed by comparison of Ni-3 and Ni-4, in which the latter exhibited a TOF $\left(1737 \mathrm{~s}^{-1}\right)$ almost 5 times greater than that of Ni-3 $\left(342 \mathrm{~s}^{-1}\right)$. The values of the TOF have also been confirmed by the FOWA method (Fig. S27 $\dagger)^{24 a, b}$. The results from the two methods show the same trend that the $\beta$-hydrogenation of the pyrrole ring enhances the reactivities of the nickel porphyrinoids, with the TOF of Ni-2 > $\mathrm{Ni}-1$, and Ni-4 $>\mathrm{Ni}-3$. It is worth nothing that replacement of the $\beta$-lactone moiety results in comparable reactivity to the porphyrin analogue (Ni-1 vs. Ni-3) but much lower reactivity than the chlorin complex ( $\mathrm{Ni}-2$ vs. Ni-4). Thus, these results clearly demonstrate that $\beta$-hydrogenation of porphyrin or porpholactone can remarkably enhance catalytic HER reactivity.

With the plateau current of the catalytic S-shaped voltammograms appearing at the second reduction peak of the nickel complexes, we considered that the electrochemical-electrochemical-chemical-chemical (EECC) mechanism (pathway A) might be the most plausible mechanism (Scheme 2). ${ }^{25}$ However

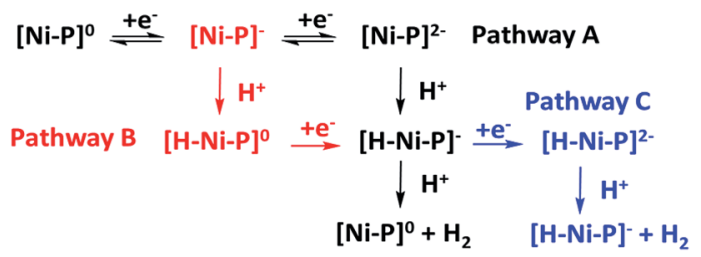

Scheme 2 Possible heterolytic reaction pathways in the nickel porphyrin catalyzed HER process. other reaction pathways cannot be excluded. The catalytic onset can appear at the first reduction wave with a stronger acid such as methylsulfonic acid ( $\mathrm{MsOH})$ (Fig. S28†). In this situation the acid might be strong enough to hydrogenate $[\mathrm{Ni}-\mathrm{P}]^{-}$to $[\mathrm{H}-\mathrm{Ni}-$ $\mathrm{P}]^{0}$, which can then be reduced to $[\mathrm{H}-\mathrm{Ni}-\mathrm{P}]^{-}$and react with anther proton to yield hydrogen (pathway B). This phenomenon has been reported by Nocera ${ }^{15}$ and $\mathrm{Cao}^{13}$. In addition, at a low acid concentration, we can observe another catalytic plateau after the catalytic current increased at the second reduction peak in Ni-3. In this situation, the $[\mathrm{H}-\mathrm{Ni}-\mathrm{P}]^{-}$might be further reduced to $[\mathrm{H}-\mathrm{Ni}-\mathrm{P}]^{2-}$ and then react with a proton to release $\mathrm{H}_{2}$ and revert back to $[\mathrm{Ni}-\mathrm{P}]^{-}$(pathway $\mathrm{C}$ ), as Savéant and coworkers previously reported. ${ }^{26}$

\section{Electronic structures of $\mathrm{Ni}-1$ to $\mathrm{Ni}-4$}

To understand the effect of $\beta$-hydrogenation of porphyrins on the reactivity of Ni complexes, DFT calculations were carried out to optimize the electronic structures (see more computational details in the ESI $\dagger$ ). The most stable forms of $[\mathrm{Ni}-1]^{0},[\mathrm{Ni}-2]^{0}$ and $[\mathrm{Ni}-4]^{0}$ are saddle-shaped closed-shell singlets, and $[\mathrm{Ni}-3]^{0}$ is most stable in a flat closed-shell singlet, in accordance with the ${ }^{1} \mathrm{H}-\mathrm{NMR}$ spectra and crystal structures. The one-electron reduced nickel complexes have the most stable doublet flat geometries with a Mulliken spin density $\left(\rho_{\mathrm{Ni}}\right)$ of approximately 1.0 on the Ni center, indicating a formal Ni(I) species. Interestingly, the two-electron reduced nickel complexes have different electronic structures as shown in Fig. 5. For $[\mathrm{Ni}-1]^{2-}$ and $[\mathrm{Ni}-3]^{2-}$, the flat triplet is lower in energy than the closedshell bent singlet and two unpaired electron are localized on the porphyrin macrocycle. Small Mulliken spin densities $\left(\rho_{\mathrm{Ni}} \mathrm{s}\right)$ of 0.0026 and 0.36 were obtained for $[\mathrm{Ni}-1]^{2-}$ and $[\mathrm{Ni}-3]^{2-}$, 

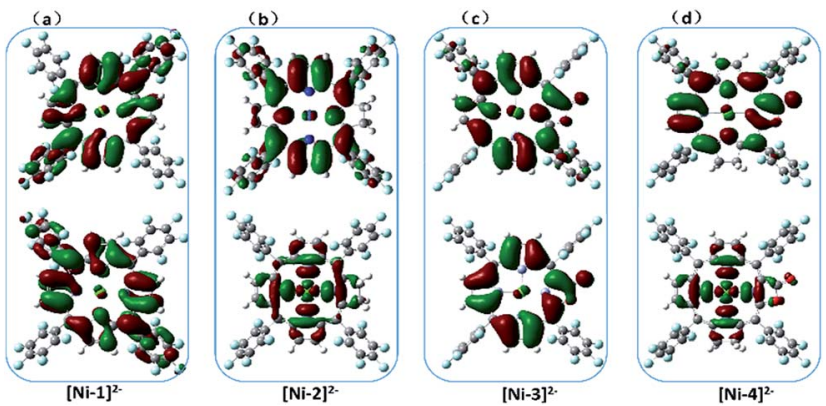

Fig. 5 The calculated (B3LYP) SOMO+1 (top) and SOMO (bottom) of $[\mathrm{Ni}-1]^{2-}(\mathrm{a}),[\mathrm{Ni}-2]^{2-}(\mathrm{b}),[\mathrm{Ni}-3]^{2-}$ (c) and $[\mathrm{Ni}-4]^{2-}$ (d) showing the different electronic structures.

respectively (Tables S9 and S11†), suggesting a Ni(II) porphyrin diradical consistent with the above spectroelectrochemistry results. Additionally, the singly occupied molecular orbitals (SOMO) of $[\mathrm{Ni}-1]^{2-}$ and $[\mathrm{Ni}-3]^{2-}$ also showed that the electron density was almost located on the porphyrin $\beta$-periphery (Fig. 5a and c). However, Nocera and his coworker's reported an analogue of $[\mathrm{Ni-1}]^{2-}$ (meso-chlorine atoms were used to replace the meso-pentafluorophenyl substituents of nickel porphyrin in his work) which was a flat triplet species with a Mulliken spin density of almost 1 on the $\mathrm{Ni}$ center and almost 1 on the ligands. ${ }^{15}$ As shown in Fig. S34, $\dagger$ we find that a meso-substitutional group affects the calculation results. In addition, five different DFT functionals have been used (B3LYP, B3P86, BP86, BLYP and M06L) to confirm our results. The above indicated that using $6-31+\mathrm{G}(\mathrm{d})$ as the basis set, LAN2DZ as the pseudopotential and B3LYP as functional is reasonable.

In sharp contrast, the two-electron reduced $[\mathrm{Ni}-2]^{2-}$ and $[\mathrm{Ni}-$ $4]^{2-}$ possess the most stable flat triplet with Mulliken spin densities on the nickel center of $\rho_{\mathrm{Ni}}=1.22$ and 0.95 (Tables $\mathrm{S} 10$ and $\mathrm{S} 12 \dagger$ ), indicating that one unpaired electron is localized on the nickel center and another on the macrocycle. The calculated SOMOs of $[\mathrm{Ni}-2]^{2-}$ and $[\mathrm{Ni}-4]^{2-}$ also showed that one unpaired electron is localized on the $\sigma^{*}\left(d_{x^{2}-y^{2}}\right)$ orbital of the Ni center, and another is delocalized on the porphyrin, indicating a $\mathrm{Ni}(\mathrm{I})$ porphyrin radical (Fig. 5b and d).

\section{DFT calculated formation of $[\mathrm{Ni}-1-\mathrm{H}]^{-}$and $[\mathrm{H}-\mathrm{Ni}-2]^{-}$}

Since HER occurred at the second reduction peak experimentally, we further used the relative free energies to compare the formation and reactivity of the hydride intermediate from [ $\mathrm{Ni}-$ $1]^{2-}$ and $[\mathrm{Ni}-2]^{2-}$, as shown in Fig. 6. Protonation of $[\mathrm{Ni}-1]^{2-}$ by TFA was found to be thermodynamically downhill by $7.7 \mathrm{kcal}$ $\mathrm{mol}^{-1}$ (Fig. 6a) but protonation of $[\mathrm{Ni}-1]^{-}$was thermodynamically uphill by $32.2 \mathrm{kcal} \mathrm{mol}^{-1}$ (Fig. S36†). Thus, starting from $[\mathrm{Ni}-1]^{2-}$ is thermodynamically preferred, which is consistent with the experimental CVs in that the HER occurred at $c a$. $-1.80 \mathrm{~V}$. The resulting exothermal product, $[\mathrm{Ni}-\mathrm{1}-\mathrm{H}]^{-}$, was formed through a stretching vibration between the $\mathrm{H}$ and $\mathrm{N}$ transition state TS1 with an energy barrier of $18.5 \mathrm{kcal} \mathrm{mol}^{-1}$. To find the protonation intermediate, four protonation sites were tested: the meso-carbon (metallophlorin intermediate), the $\beta$ carbon, the pyrrolic nitrogen and the nickel center (metal hydride), and we chose the most thermodynamically favored pyrrolic nitrogen protonated one as the intermediate. In addition, for the pyrrolic nitrogen we could find a transition state (Fig. S35c $\dagger$ ). The IRC path showed that the $\mathrm{H}$-atom went through a stretching vibration and the porphyrin ring changed from being flat to ruffled. This phenomenon indicates that the protonation of $[\mathrm{Ni}-\mathbf{1}]^{2-}$ to $[\mathrm{Ni}-\mathbf{1}-\mathrm{H}]^{-}$occurred, since $[\mathrm{Ni}-\mathbf{1}]^{2-}$ is a flat triplet and $[\mathrm{Ni}-\mathbf{1}-\mathrm{H}]^{-}$is a bent singlet. Then $[\mathrm{Ni}-\mathbf{1}-\mathrm{H}]^{-}$ could react with another TFA to release $\mathrm{H}_{2}$ exothermically by $22.3 \mathrm{kcal} \mathrm{mol}^{-1}$, regenerating the neutral $[\mathrm{Ni}-1]^{0}$. For Ni-2, the protonations of $[\mathrm{Ni}-2]^{-}$and $[\mathrm{Ni}-2]^{2-}$ were both thermodynamically uphill by 29.5 and $4.8 \mathrm{kcal} \mathrm{mol}^{-1}$, respectively, and $[\mathrm{Ni}-2]^{2-}$ was thermodynamically favourable (Fig. S37 $\dagger$ ). To find the protonation intermediate for $\mathrm{Ni}-2$, the four protonation sites were also tested and the most thermodynamically favored metal hydride was chosen. We could also find a transition state (Fig. S35d †) and the IRC path showed that the generation of [H$\mathrm{Ni}-2]^{-}$is through a transition state (TS2) with an energy barrier of $15.2 \mathrm{kcal} \mathrm{mol}^{-1}$, which is $3.3 \mathrm{kcal} \mathrm{mol}^{-1}$ lower than TS1. The reaction of $[\mathrm{H}-\mathrm{Ni}-2]^{-}$with another proton was also exothermic by $31.9 \mathrm{kcal} \mathrm{mol}^{-1}$.

Interestingly, for $[\mathrm{Ni}-2]^{2-}$, the proton of TFA approaches the electron rich nickel center at a distance of $1.49 \AA$, positioned
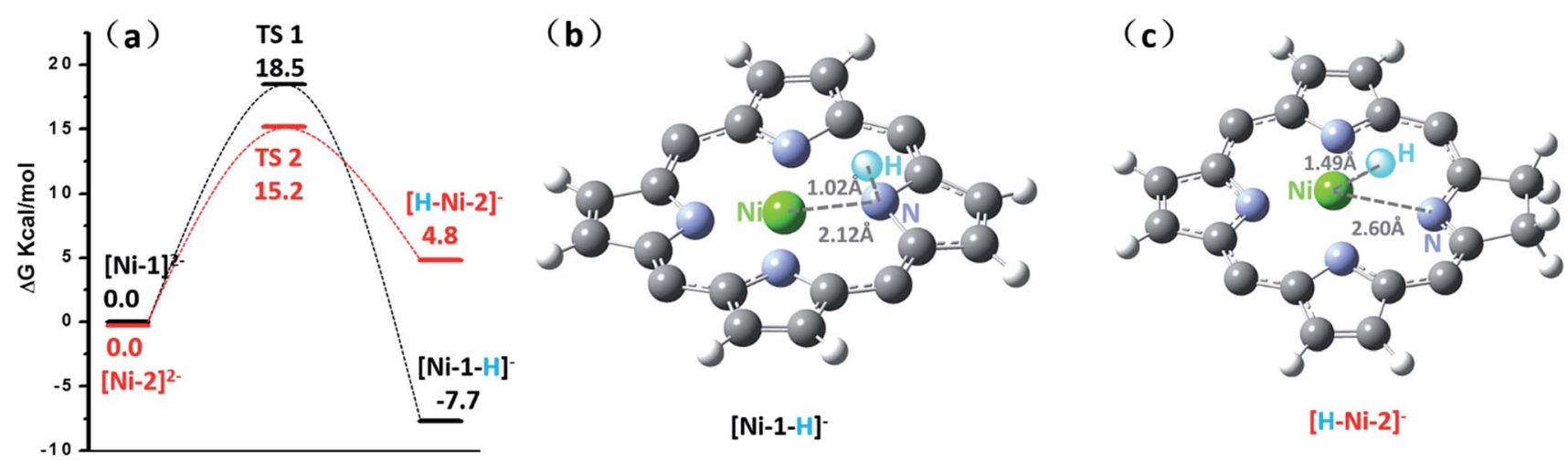

Fig. 6 (a) Free energy diagram for the formation of $[\mathrm{Ni}-1-\mathrm{H}]^{-}$(black line) and $[\mathrm{H}-\mathrm{Ni}-2]^{-}$(red line) intermediates during the HER process. Freeenergy values are given in $\mathrm{kcal} \mathrm{mol}^{-1}$. The geometric conformation of $[\mathrm{Ni}-1-\mathrm{H}]^{-}$(b) and $[\mathrm{H}-\mathrm{Ni}-2]^{-}$(c) active intermediates during the HER process. 
obliquely to the pyrrolic nitrogen in the porphyrin ring, indicating a metal hydride-like intermediate $[\mathrm{H}-\mathrm{Ni}-2]^{-}$(Fig. 6c).

However, in $[\mathrm{Ni}-1]^{2-}$, the proton bonds to the pyrrolic nitrogen and forms an $\mathrm{N}-\mathrm{H}$ bond with a length of $1.02 \AA$. Further insight into the bonding characteristics of the proton adducts was gained from analysis of the Mulliken atomic charges of $[\mathrm{Ni}-1-\mathrm{H}]^{-}(0.397)$ and $[\mathrm{H}-\mathrm{Ni}-2]^{-}(-0.016)$ (Fig. S33 $\left.\dagger\right)$. This demonstrated that the hydrogen atom of $[\mathrm{Ni}-2-\mathrm{H}]^{-}$is more electronegative than the hydride of $[\mathrm{H}-\mathrm{Ni}-\mathbf{1}]^{-}$, and might prefer to react with another TFA molecule via a heterolytic pathway.

\section{Spectroelectrochemical TFA titration of $[\mathrm{Ni}-1]^{2-}$ and $[\mathrm{Ni}-2]^{2-}$}

To verify the reactivity of the two intermediates, $[\mathrm{Ni}-1]^{2-}$ and $[\mathrm{Ni}-$ $2]^{2-}$, we carried out redox titrations of the nickel complexes in acetonitrile solution using $\mathrm{Co}\left(\mathrm{Cp}^{*}\right)_{2}\left(E_{\mathrm{ox}}=-1.90 \mathrm{~V} v s . \mathrm{Fc}^{+} / \mathrm{Fc}\right)$ as a chemical reductant. The one-electron oxidation potential of $\mathrm{Co}\left(\mathrm{Cp}^{*}\right)_{2}$ is lower than the two-electron reduction potential of $\mathrm{Ni}-1$ and $\mathrm{Ni}-2$. Thus, the addition of $\mathrm{Co}\left(\mathrm{Cp}^{*}\right)_{2}$ led to the formation of $[\mathrm{Ni}-1]^{2-}$ or $[\mathrm{Ni}-2]^{2-}$, which is evidenced by the similarity of the UV-vis absorption spectra to those obtained via spectroelectrochemistry (Fig. S29 and S30 $\dagger$ ). The addition of excess TFA to the solution of $[\mathrm{Ni}-1]^{2-}$ or $[\mathrm{Ni}-2]^{2-}$ resulted in fast conversion to $\mathrm{Ni}-\mathbf{1}$ or $\mathrm{Ni}-2$ (Fig. 7a), accompanied by the formation of $\mathrm{H}_{2}$ bubbles. The overall two-step kinetics reaction mechanisms of $\mathrm{H}_{2}$ production are shown in Scheme 2 (pathway A). The first proton addition step might be very fast and the second step might be the rate-determining step. ${ }^{27 a-c}$ As shown in Fig. 7a, $[\mathrm{Ni}-2]^{2-}$ displayed much larger $k_{\text {obs }}\left(0.27 \mathrm{~s}^{-1}\right)$ than $[\mathrm{Ni}-$ $1]^{2-}\left(6.2 \times 10^{-3} \mathrm{~s}^{-1}\right)$ (pseudo-first-order kinetic model), as exemplified in the presence of 100 equiv. of TFA at $10{ }^{\circ} \mathrm{C}$. Secondary reaction kinetics constants $k_{2} \mathrm{~S}$ for $[\mathrm{Ni}-1]^{2-}$ and $[\mathrm{Ni}-$ $2]^{2-}$ of $9.17 \times 10^{-2}$ and $3.03 \mathrm{M}^{-1} \mathrm{~s}^{-1}$, respectively, were obtained by linearly fitting $k_{\mathrm{obs}} \mathrm{s} v s$. TFA concentration (Fig. 7b). Similar enhancement of the titration reaction rates to
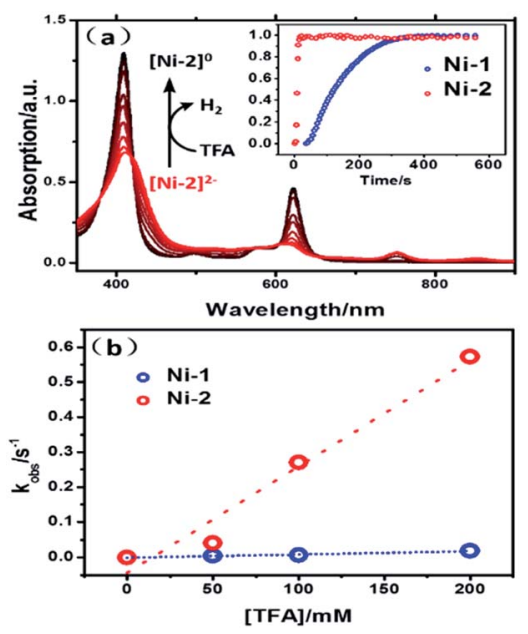

Fig. 7 (a) UV-vis absorption spectra of the process of $[\mathrm{Ni}-2]^{2-}$ reacting with TFA. Inset: plot of the absorption of the Soret band $v$ s. time for the reaction of $[\mathrm{Ni}-1]^{2-}$ (blue line) and $[\mathrm{Ni}-2]^{2-}$ (red line) with 100 equiv. TFA at $10^{\circ} \mathrm{C}$. (b) Plot of $k_{\mathrm{obs}} v s$. concentration of TFA for the reaction of $[\mathrm{Ni}-1]^{2-}$ (blue line) and $[\mathrm{Ni}-2]^{2-}$ (red line) with TFA.

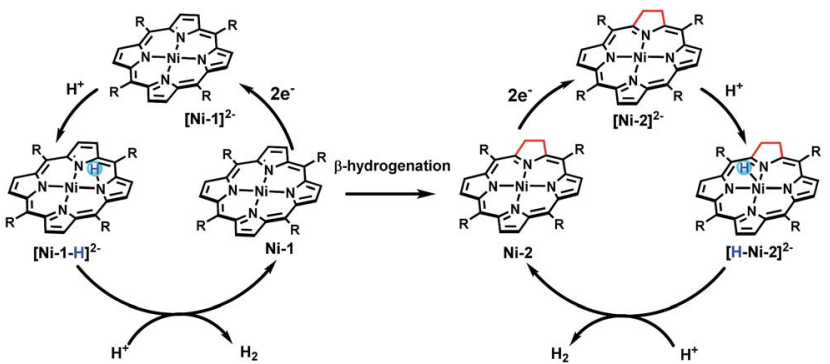

Scheme 3 The proposed mechanism for nickel compound-catalyzed HER.

electrocatalytic HER clearly demonstrated the importance of disrupted conjugation on the electronic structures and the reactivity of reduced $\mathrm{Ni}$ complexes, which is consistent with DFT calculation results.

\section{Conclusion}

Taken together, we demonstrated for the first time that $\beta$ hydrogenation of porphyrin is important for enhancing the HER reactivity using nickel porphyrinoids. Experimental and theoretical studies showed that $\beta$-hydrogenation significantly affects the electronic structures of the two-electron reduced $\mathrm{Ni}$ complexes and renders more electron density localized on the $\mathrm{Ni}$ center in $[\mathrm{Ni}-2]^{2-}$ and $[\mathrm{Ni}-4]^{2-}$ than $[\mathrm{Ni}-1]^{2-}$ and $[\mathrm{Ni}-3]^{2-}$. Thus, as shown in Scheme 3, protonation of $[\mathrm{Ni}-2]^{2-}$ leads to a typical metal hydride intermediate $[\mathrm{H}-\mathrm{Ni}-2]^{2-}$, while $[\mathrm{Ni}-1]^{2-}$ only affords a ligand centred hydride $[\mathrm{Ni}-\mathbf{1}-\mathrm{H}]^{2-}$. $[\mathrm{H}-\mathrm{Ni}-\mathbf{2}]^{-}$ prefers to react with another proton via a quick heterolytic pathway as demonstrated by the time course results of reacting with TFA. This work also provides an opportunity to further design metal molecular catalysts with subtle structural ligand changes inspired by natural metal cofactors.

\section{Experimental section}

\section{General procedures}

Commercially available solvents were used after being purified by the MBraun SPS-800 Solvent Purification System. Deuterium solvents were stored with 4 A molecular sieves. Manipulations of air and moisture sensitive materials were performed in a glove box in an atmosphere of argon. $\mathrm{CH}_{3} \mathrm{CN}$ and dimethylformamide were distilled and degassed before use. Tetrabutylammonium hexafluorophosphate $\left({ }^{n} \mathrm{Bu}_{4} \mathrm{NPF}_{6}\right)$ was recrystallized from absolute ethanol. Other reagents were purchased from commercial suppliers and used without purification. UV-vis spectra were recorded on an Agilent 8453 UV-vis spectrometer equipped with an Agilent 89090A thermostat $\left( \pm 0.1{ }^{\circ} \mathrm{C}\right)$. ESI-MS were recorded on a Bruker APEX IV Fourier Transform Ion Cyclotron Resonance Mass Spectrometer using electrospray ionization. ${ }^{1} \mathrm{H},{ }^{19} \mathrm{~F}$ and ${ }^{13} \mathrm{C}$ NMR spectra were recorded on a Bruker-400 $\mathrm{MHz}$ NMR. All ${ }^{1} \mathrm{H}$ NMR experiments were reported in $\delta$ units, parts per million (ppm), and all coupling constants were in $\mathrm{Hz}$ and measured relative to the 
signal for residual chloroform $(7.26 \mathrm{ppm})$ in the deuterated solvent $\mathrm{CDCl}_{3}$. For the ${ }^{19} \mathrm{~F}$ NMR spectra, $\mathrm{CF}_{3} \mathrm{COOH}$ was used as an external reference at $0 \mathrm{ppm}$. Transmission electron microscopy was carried out using a JEM-2100F(JEOL). DLS measurements were made using a Laser Light Scattering Spectrometer (ALV/Laser Vertriebsgesellschaft m.b.H), which can detect particle sizes ranging from $1.0 \mathrm{~nm}$ to $1.0 \mu \mathrm{m}$. SEM and EDX were performed using a Hitachi S-4800 field emission scanning electron microscope at accelerating voltages of 5 and $15 \mathrm{kV}$, respectively. Elemental analyses were carried out on an Elementar Vario EL CUBE (Germany). Cyclic voltammetry experiments were recorded on Shanghai Chenhua CHI660C electrochemical workstation. A glassy carbon electrode was selected as the working electrode, the auxiliary electrode was a platinum wire electrode and $\mathrm{Ag} / \mathrm{AgCl}$ was the reference electrode. All samples were recorded in acetonitrile with $0.1 \mathrm{M}$ ${ }^{n} \mathrm{Bu}_{4} \mathrm{NPF}_{6}$ as the electrolyte, the scan rate was $0.1 \mathrm{~V} \mathrm{~s}^{-1}$ and the $E_{1 / 2}$ were calculated based on peak position for the internal standard $\mathrm{FeCp}_{2}\left(E_{1 / 2}=0.45 \mathrm{~V}\right.$ vs. SCE $)$.

\section{Synthesis of free base porphyrinoids 1-4}

meso-Tetrakispentafluorophenylporphyrin (1), meso-tetrakispentafluorophenylchlorin (2), meso-tetrakispentafluorophenylporpholactone (3) and adjacent-hydroporpholactone (4) were synthesized according to the literature. ${ }^{16 c, 17}$

\section{Synthesis of Ni-1 to Ni-4}

Typical procedure. Porphyrin free base ligand $(0.1 \mathrm{mmol})$ was refluxed with 30 equiv. of $\mathrm{Ni}(\mathrm{OAc})_{2}(1 \mathrm{mmol}, 180 \mathrm{mg})$ in acetonitrile under nitrogen for 6 hours. The solvent was removed by adding 100 equivalents of water and the residue was purified through a silica column.

Ni-1. Isolated yields were over $90 \%$. Eluent: ethyl acetate : petroleum ether, $1: 5 .{ }^{1} \mathrm{H} \mathrm{NMR}\left(400 \mathrm{MHz} \mathrm{CDCl}_{3}\right) \delta 8.81(\mathrm{~s}$, 8H). ${ }^{19} \mathrm{~F} \mathrm{NMR}\left(377 \mathrm{MHz}, \mathrm{CDCl}_{3}\right) \delta-136.47(\mathrm{dd}, J=23.2,7.7 \mathrm{~Hz}$, $8 \mathrm{~F}),-150.17(\mathrm{~m}, 4 \mathrm{H}),-161.32(\mathrm{dt}, J=22.5,7.4 \mathrm{~Hz}, 8 \mathrm{~F}) .{ }^{13} \mathrm{C} \mathrm{NMR}$ $\left(101 \mathrm{MHz}, \mathrm{CDCl}_{3}\right.$ ) $\delta 142.98$ (s), 132.52 (s), 103.09 (s). ESI-MS m/z: calcd for $\mathrm{C}_{44} \mathrm{H}_{8} \mathrm{~F}_{20} \mathrm{~N}_{4} \mathrm{Ni}$ 1029.97831, found 1029.97854. Anal. calcd for $\mathrm{C}_{44} \mathrm{H}_{8} \mathrm{~F}_{20} \mathrm{~N}_{4} \mathrm{Ni}$ : C, 51.25; H, 0.78; N, 5.43, found $\mathrm{C}$, 51.29; H, 0.92; N, 5.38.

Ni-2. Isolated yields were $75 \%$. Eluent: ethyl acetate : petroleum ether, $1: 10 .{ }^{1} \mathrm{H}$ NMR $\left(400 \mathrm{MHz}, \mathrm{CDCl}_{3}\right) \delta=8.29(\mathrm{~d}, J=$ $4.9 \mathrm{~Hz}, 2 \mathrm{H}), 8.14$ (s, 2H), $7.95(\mathrm{~d}, J=5.0 \mathrm{~Hz}, 2 \mathrm{H}), 3.93(\mathrm{~s}, 4 \mathrm{H}) .{ }^{19} \mathrm{~F}$ NMR (377 MHz, $\left.\mathrm{CDCl}_{3}\right) \delta=-136.94(\mathrm{dd}, J=23.2,7.7 \mathrm{~Hz}, 4 \mathrm{~F})$, -137.89 (dd, $J=23.8,8.3 \mathrm{~Hz}, 4 \mathrm{~F}),-151.88$ (t, $J=20.9 \mathrm{~Hz}, 2 \mathrm{~F})$, $-152.10(\mathrm{t}, J=20.9 \mathrm{~Hz}, 2 \mathrm{~F}),-160.66(\mathrm{dt}, J=23.3,8.0 \mathrm{~Hz}, 4 \mathrm{~F})$, -161.57 (dt, $J=22.6,7.4 \mathrm{~Hz}, 4 \mathrm{~F}) .{ }^{13} \mathrm{C} \mathrm{NMR}\left(101 \mathrm{MHz}, \mathrm{CDC}_{\mathrm{l}}\right.$ ) $\delta 169.03$ (s), 152.66 (s), 140.39 (s), 135.31 (s), 132.27 (s), 128.22 (s), 123.62 (s), $106.31(\mathrm{~s}), 96.83(\mathrm{~s}), 35.31$ (s, $\left.-\mathrm{CH}_{2}{ }^{-}\right)$. ESI-MS m/z: calcd for $\mathrm{C}_{44} \mathrm{H}_{10} \mathrm{~F}_{20} \mathrm{~N}_{4} \mathrm{Ni}$ 1031.99396, found 1031.98981. Anal. calcd for $\mathrm{C}_{44} \mathrm{H}_{10} \mathrm{~F}_{20} \mathrm{~N}_{4} \mathrm{Ni}$ : C, 51.15; H, 0.98; N, 5.42, found C, 51.16; H, 1.14; $\mathrm{N}, 5.31$.

Ni-3. Isolated yields were over $90 \%$. Eluent: ethyl acetate : petroleum ether, $1: 5 .{ }^{1} \mathrm{H} \mathrm{NMR}\left(400 \mathrm{MHz} \mathrm{CDCl}_{3}\right) \delta 8.67$ (d, $J=5.1 \mathrm{~Hz}, 1 \mathrm{H}), 8.65-8.61(\mathrm{~m}, 2 \mathrm{H}), 8.58(\mathrm{~d}, J=5.1 \mathrm{~Hz}, 1 \mathrm{H}), 8.55$ $(\mathrm{d}, J=4.9 \mathrm{~Hz}, 2 \mathrm{H}) .{ }^{19} \mathrm{~F}$ NMR $\left(377 \mathrm{MHz}, \mathrm{CDCl}_{3}\right) \delta-136.69$ to $-136.96(\mathrm{~m}),-138.17$ to $-138.39(\mathrm{~m}),-150.28$ to $-150.62(\mathrm{~m})$, $-151.20(\mathrm{q}, J=20.9 \mathrm{~Hz}),-160.27$ to $-160.87(\mathrm{~m}),-161.37$ (qd, $J=22.1,6.8 \mathrm{~Hz}) .{ }^{13} \mathrm{C} \mathrm{NMR}\left(101 \mathrm{MHz}, \mathrm{CDCl}_{3}\right) \delta 163.03(\mathrm{~s}), 149.75$ (s), 144.95 (s), 134.45 (s), 132.47 (d), 131.78 (s), 131.17 (s), 130.34 (s), 120.59 (s). ESI-MS $m / z$ : calcd for $\mathrm{C}_{43} \mathrm{H}_{6} \mathrm{~F}_{20} \mathrm{~N}_{4} \mathrm{NiO}_{2}$ 1048.95556, found 1048.95959. Anal. calcd for $\mathrm{C}_{43} \mathrm{H}_{6} \mathrm{~F}_{20} \mathrm{~N}_{4} \mathrm{NiO}_{2}$ : C, 49.23; H, 0.58; N, 5.34, found C, 48.66; H, 0.67; N, 5.26.

Ni-4. Isolated yields were over $90 \%$. Eluent: ethyl acetate : petroleum ether, $1: 5 .{ }^{1} \mathrm{H}$ NMR $\left(400 \mathrm{MHz} \mathrm{CDCl}_{3}\right) \delta 7.97$ (d, $J=4.8 \mathrm{~Hz}, 1 \mathrm{H}), 7.77(\mathrm{dd}, J=20.5,4.5 \mathrm{~Hz}, 2 \mathrm{H}), 7.54(\mathrm{~d}, J=4.7 \mathrm{~Hz}$, $1 \mathrm{H}), 3.76$ (d, $J=8.4 \mathrm{~Hz}, 2 \mathrm{H}), 3.66$ (d, $J=8.4 \mathrm{~Hz}, 2 \mathrm{H}) .{ }^{19} \mathrm{~F} \mathrm{NMR}$ $\left(377 \mathrm{MHz}, \mathrm{CDCl}_{3}\right) \delta-137.63(\mathrm{~d}, J=23.9 \mathrm{~Hz}),-137.89(\mathrm{~d}, J=$ $15.5 \mathrm{~Hz}),-138.76(\mathrm{~d}, J=15.8 \mathrm{~Hz}),-151.16(\mathrm{~d}, J=34.0 \mathrm{~Hz})$, $-151.50(\mathrm{~s}),-151.79(\mathrm{~s}),-160.07(\mathrm{~d}, J=6.2 \mathrm{~Hz}),-160.31(\mathrm{~d}, J=$ $5.9 \mathrm{~Hz}),-160.68(\mathrm{~d}, J=6.1 \mathrm{~Hz}),-161.42(\mathrm{~d}, J=5.9 \mathrm{~Hz}) .{ }^{13} \mathrm{C}$ NMR (101 MHz, $\mathrm{CDCl}_{3}$ ) $\delta 165.72(\mathrm{~s},-\mathrm{C}=\mathrm{O}), 162.06(\mathrm{~s}), 156.20$ (s), 151.18 (s), 149.93 (s), 141.77 (s), 139.34 (s), 138.75 (s), 133.28 (s), 127.83 (s), 126.19 (s), 115.90 (s), 96.88 (s), 82.19 (s), 34.40 (s, $\left.-\mathrm{CH}_{2}-\right)$, $32.29\left(\mathrm{~s},-\mathrm{CH}_{2}-\right)$. Calcd for $\mathrm{C}_{43} \mathrm{H}_{8} \mathrm{~F}_{20} \mathrm{~N}_{4} \mathrm{NiO}_{2}[\mathrm{M}+\mathrm{H}]^{+}$ 1050.97586, found 1050.97686. Anal. calcd for $\mathrm{C}_{43} \mathrm{H}_{8} \mathrm{~F}_{20} \mathrm{~N}_{4} \mathrm{NiO}_{2}$ : C, 49.13; H, 0.77; N, 5.33, found C, 48.96; H, 0.93; N, 5.20.

\section{Cyclic voltammetry}

Cyclic voltammetry was performed with a CHI 660C instrument. A glassy carbon (3 $\mathrm{mm}$ diameter) was used as the working electrode, a platinum filament as the counter electrode, and Ag/ $\mathrm{AgCl}$ as the reference electrode. Solvents were purified by an MBraun SPS-800 Solvent Purification System. All samples were recorded in dichloromethane with $0.1 \mathrm{M}^{n} \mathrm{Bu}_{4} \mathrm{NPF}_{6}$ as the electrolyte. Unless otherwise noted, all potentials in this study were adjusted to the ferrocenium/ferrocene $\left(\mathrm{Fc}^{+/ 0}\right)$ couple as an internal standard.

\section{Spectroelectrochemistry studies}

Spectroelectrochemical measurements were carried out in a quartz cell with an optical path length of $1 \mathrm{~cm}$. A platinum net, platinum filament and $\mathrm{Ag} / \mathrm{AgCl}$ were used as the working electrode, counter electrode, and reference electrode, respectively. The sample solutions were deaerated with acetonitrilesaturated argon. The spectra were recorded on an Agilent 8453 UV-vis spectrophotometer during electrolysis on a $\mathrm{CHI}$ 660C instrument.

\section{Controlled-voltage coulometry experiment}

Bulk electrolysis was performed with a CHI 660C instrument with a glassy carbon $(1 \mathrm{~cm} \times 1 \mathrm{~cm})$ as the working electrode. The reference electrode was an aqueous $\mathrm{Ag} / \mathrm{AgCl}$ electrode, and the counter electrode was a platinum wire and $0.1 \mathrm{M}^{n} \mathrm{Bu}_{4} \mathrm{NPF}_{6}$ in $\mathrm{CH}_{3} \mathrm{CN}$ solution. The volume of the electrolysis solution was $20 \mathrm{~mL}$. The reference electrode was directly immersed in the solution to minimize ohmic drop. The gas phase in the head space was analyzed by GC with Ar as the carrier gas. A hydrogen calibration curve was obtained by filling a tube with pure hydrogen gas with a graduated gastight syringe. 


\section{Chemistry titration}

Acetonitrile solutions of Ni-1 or Ni-2 $\left(1.6 \times 10^{-5} \mathrm{M}\right)$ and $\mathrm{Co}\left(\mathrm{Cp}^{*}\right)_{2}\left(9.3 \times 10^{-4} \mathrm{M}\right)$ were prepared in the glove box and stored in airtight cuvettes and vials respectively. The solutions of Ni-1 or Ni-2 and $25 \mu \mathrm{L} \mathrm{Co}\left(\mathrm{Cp}^{*}\right)_{2}$ (1 equivalent) were mixed and the UV-Vis spectra were recorded immediately after the mixing.

\section{Computational details}

All geometry optimization calculations were performed using the density functional theory (DFT) functional B3LYP/6-31G+(d) as the basis set and LAN2DZ as the pseudopotential as implemented in the Gaussian 09 software. The solvent effect was considered in all geometry optimizations and property calculations using the conductor-like polarizable continuum model (CPCM). The energies were corrected by single point calculations using B3LYP/6-31+G(d,p) as the basis set. For the absolute solvation free energy of the proton in acetonitrile, a value of $-260.2 \mathrm{kcal} \mathrm{mol}^{-1}$ was used..$^{28}$ The frequency calculations at the same level were carried out to confirm each stationary point to be either a minimum or transition state. Intrinsic reaction coordinate (IRC) paths were calculated to connect each TS to the corresponding reactant and product.

\section{Acknowledgements}

We acknowledge financial support from the National Key Basic Research Support Foundation of China (Grant 2015CB856301) and the National Scientific Foundation of China (Grants 21571007, 21271013, 21321001). X. R. He is gratefully thanked for help with the ESI-MS, Z.-C. Huang and H. Zhu are gratefully thanked for help with the DFT calculation parts, T. Huang is gratefully thanked for help with DLS, T.-T. Zuo is gratefully thanked for help with TEM, and Y.-Y. Yuan is gratefully thanked for help with SEM and EDX.

\section{Notes and references}

1 (a) K. M. Kadish, K. M. Smith and R. Guilard, Handbook of Porphyrin Science with Applications to Chemistry, Physics, Materials Science, Engineering, Biology and Medicine, World Scientific, 2014; (b) H.-B. Kraatz and N. Metzler-Nolte, Concepts and Models in Bioinorganic Chemistry, Wiley-VCh, New York, 2006; (c) Y. M. Sung, J. Oh, W. Y. Cha, W. Kim, J. M. Lim, M. C. Yoon and D. Kim, Chem. Rev., 2016, 117, 2257-2312; (d) R. D. Teo, J. Y. Hwang, J. Termini, Z. Gross and H. B. Gray, Chem. Rev., 2016, 114, 2177-2729; (e) W. Zhang, W. Lai and R. Cao, Chem. Rev., 2016, 117, 37173797.

2 (a) L.-L. Li and E. W.-G. Diau, Chem. Soc. Rev., 2013, 42, 291304; (b) M. R. Wasielewski, Acc. Chem. Res., 2009, 42, 19101921.

3 (a) M. Ethirajan, Y. Chen, P. Joshi and R. K. Pandey, Chem. Soc. Rev., 2011, 40, 340-362; (b) A. P. Castano, P. Mroz and M. R. Hamblin, Nat. Rev. Cancer, 2006, 6, 535-545.

4 (a) C. M. Drain, A. Varotto and I. Radivojevic, Chem. Rev., 2009, 109, 1630-1658; (b) R. Paolesse, S. Nardis, D. Monti,
M. Stefanelli and C. Di Natale, Chem. Rev., 2017, 117, 25172583; (c) Y. Ding, W. H. Zhu and Y. Xie, Chem. Rev., 2016, 117, 2203-2256.

5 (a) M. Kruger, A. Meyerdierks, F. O. Glockner, R. Amann, F. Widdel, M. Kube, R. Reinhardt, R. Kahnt, R. Bocher, R. K. Thauer and S. Shima, Nature, 2003, 426, 878-881; (b) T. J. Lawton and A. C. Rosenzweig, J. Am. Chem. Soc., 2016, 138, 9327-9340.

6 (a) W. L. Ellefson, W. B. Whitman and R. S. Wolfe, Proc. Natl. Acad. Sci. U. S. A., 1982, 79, 3707-3710; (b) S. J. Moore, S. T. Sowa, C. Schuchardt, E. Deery, A. D. Lawrence, J. V. Ramos, S. Billig, C. Birkemeyer, P. T. Chivers, M. J. Howard, S. E. Rigby, G. Layer and M. J. Warren, Nature, 2017, 543, 78-82.

7 (a) K. C. Bible, M. Buytendorp, P. D. Zierath and K. L. Rinehart, Proc. Natl. Acad. Sci. U. S. A., 1988, 85, 4582-4586; (b) L. A. Andersson, A. Huff and K. M. Smith, Biophys. J., 1990, 57, A232.

8 (a) K. Kadish, M. Franzen, B. Han, C. Araullo-McAdams and D. Sazou, J. Am. Chem. Soc., 1991, 113, 512-517; (b) J. Telser, Y.-C. Fann, M. W. Renner, J. Fajer, S. Wang, H. Zhang, R. A. Scott and B. M. Hoffman, J. Am. Chem. Soc., 1997, 119, 733-743; (c) A. Atifi and M. D. Ryan, Anal. Chem., 2015, 87, 12245-12253; (d) F. V. Lovecchio, E. S. Gore and D. H. Busch, J. Am. Chem. Soc., 1974, 96, 3109-3118.

9 (a) H. B. Gray, Nat. Chem., 2009, 1, 7; (b) D. Gust, T. A. Moore and A. L. Moore, Acc. Chem. Res., 2009, 42, 1890-1898; (c) C. G. Moralesguio, L. A. Stern and X. Hu, Chem. Soc. Rev., 2014, 43, 6555-6569; (d) J. X. Jian, C. Ye, X. Z. Wang, M. Wen, Z. J. Li, X. B. Li, B. Chen, C. H. Tung and L. Z. Wu, Energy Environ. Sci., 2016, 9, 2083-2089.

10 (a) M. Wang, L. Chen and L. Sun, Energy Environ. Sci., 2012, 5, 6763-6778; (b) P. Du and R. Eisenberg, Energy Environ. Sci., 2012, 5, 6012-6021; (c) V. S. Thoi, Y. Sun, J. R. Long and C. J. Chang, Chem. Soc. Rev., 2013, 42, 2388-2400; (d) J. R. Mckone, S. C. Marinescu, B. S. Brunschwig, J. R. Winkler and H. B. Gray, Chem. Sci., 2014, 5, 865-878; (e) J. Ran, J. Zhang, J. Yu, M. Jaroniec and S. Z. Qiao, Chem. Soc. Rev., 2014, 43, 7787-7812; $(f)$ B. Mondal, K. Sengupta, A. Rana, A. Mahammed, M. Botoshansky, S. G. Dey, Z. Gross and A. Dey, Inorg. Chem., 2013, 52, 3381-3387.

11 (a) W. Lubitz, H. Ogata, O. Ruediger and E. Reijerse, Chem. Rev., 2014, 114, 4081-4148; (b) J. P. Layfield and S. Hammes-Schiffer, Chem. Rev., 2014, 114, 3466-3494.

12 (a) H. Lu and X. P. Zhang, Chem. Soc. Rev., 2011, 40, 18991909; (b) C.-M. Che, V. K.-Y. Lo, C.-Y. Zhou and J.-S. Huang, Chem. Soc. Rev., 2011, 40, 1950-1975; (c) C. Kupitz, R. Fromme, I. Grotjohann and P. Fromme, in Handbook of Porphyrin Science with Applications to Chemistry, Physics, Materials Science, Engineering, Biology and Medicine, ed. G. C. Ferreira, K. M. Kadish, K. M. Smith and R. Guilard, World Scientific, Singapore, 2014, vol. 28, pp. 1-40; (d) M. O. Senge, S. A. MacGowan and J. M. O'Brien, Chem. Commun., 2015, 51, 17031-17063; (e) W. Zhang, W. Lai and R. Cao, Chem. Rev., 2017, 117, 37173797. 
13 Y. Han, H. Fang, H. Jing, H. Sun, H. Lei, W. Lai and R. Cao, Angew. Chem., Int. Ed. Engl., 2016, 55, 5457-5462.

14 D. K. Bediako, B. H. Solis, D. K. Dogutan, M. M. Roubelakis, A. G. Maher, C. H. Lee, M. B. Chambers, S. Hammes-Schiffer and D. G. Nocera, Proc. Natl. Acad. Sci. U. S. A., 2014, 111, 15001-15006.

15 B. H. Solis, A. G. Maher, D. K. Dogutan, D. G. Nocera and S. Hammes-Schiffer, Proc. Natl. Acad. Sci. U. S. A., 2016, 113, 485-492.

16 (a) X.-S. Ke, H. Zhao, X. Zou, Y. Ning, X. Cheng, H. Su and J.-L. Zhang, J. Am. Chem. Soc., 2015, 137, 10745-10752; (b) X.-S. Ke, Y. Chang, J.-Z. Chen, J. Tian, J. Mack, X. Cheng, Z. Shen and J.-L. Zhang, J. Am. Chem. Soc., 2014, 136, 9598-9607; (c) Y. Yu, T. Furuyama, J. Tang, Z.-Y. Wu, J.-Z. Chen, N. Kobayashi and J.-L. Zhang, Inorg. Chem. Front., 2015, 2, 671-677; (d) Y. Ning, X. S. Ke, J. Y. Hu, Y. W. Liu, F. Ma, H. L. Sun and J. L. Zhang, Inorg. Chem., 2017, 56, 1897-1905.

17 Y. Yu, H. Lv, X. Ke, B. Yang and J.-L. Zhang, Adv. Synth. Catal., 2012, 354, 3509-3516.

18 (a) C. Brückner, J. R. McCarthy, H. W. Daniell, Z. D. Pendon, R. P. Ilagan, T. M. Francis, L. Ren, R. R. Birge and H. A. Frank, Chem. Phys., 2003, 294, 285-303; (b) Y. Yu, B. Czepukojc, C. Jacob, Y. Jiang, M. Zeller, C. Brückner and J.-L. Zhang, Org. Biomol. Chem., 2013, 11, 4613-4621.

19 D. Lexa, M. Momenteau, J. Mispelter and J. M. Savéant, J. Inorg. Biochem., 1989, 28, 225.

20 C. J. Campbell, J. F. Rusling and C. Brückner, J. Am. Chem. Soc., 2000, 122, 6679-6685.
21 (a) A. M. Stolzenberg and M. T. Stershic, J. Am. Chem. Soc., 1988, 110, 6391-6402; (b) A. M. Stolzenberg and M. T. Stershic, J. Am. Chem. Soc., 1988, 110, 5397-5403.

22 M. W. Renner, L. R. Furenlid, K. M. Barkigia, A. Forman, H. K. Shim, D. J. Simpson, K. M. Smith and J. Fajer, J. Am. Chem. Soc., 1991, 113, 6891-6898.

23 (a) K. M. Kadish, M. M. Franzen, B. C. Han, C. Araullomcadams and D. Sazou, J. Am. Chem. Soc., 1991, 113, 512-517; (b) M. W. Renner, L. R. Furenlid, K. M. Barkigia, A. Forman, H. K. Shim, D. J. Simpson, K. M. Smith and J. Fajer, J. Am. Chem. Soc., 1991, 113, 6891-6898.

24 (a) C. Costentin, G. Passard and J. M. Savéant, J. Am. Chem. Soc., 2015, 137, 5461-5467; (b) E. S. Rountree, B. D. McCarthy, T. T. Eisenhart and J. L. Dempsey, Inorg. Chem., 2014, 53, 9983-10002.

25 V. Artero and M. Fontecave, Coord. Chem. Rev., 2005, 249, 1518-1535.

26 I. Bhugun, D. Lexa and J.-M. Savéant, J. Am. Chem. Soc., 1996, 118, 3982-3983.

27 (a) J. Kleperis, G. Wojcik, A. Czerwinski, J. Skowronski, M. Kopczyk and M. Beltowska-Brzezinska, J. Solid State Electrochem., 2001, 5, 229-249; (b) S. Mandal, S. Shikano, Y. Yamada, Y. M. Lee, W. Nam, A. Llobet and S. Fukuzumi, J. Am. Chem. Soc., 2013, 135, 15294-15297; (c) N. A. Eberhardt and H. Guan, Chem. Rev., 2016, 116, 83738426.

28 C. C. Chambers, G. D. Hawkins, C. J. Cramer and D. G. Truhlar, J. Phys. Chem., 1996, 100, 100-16385. 